\title{
Why Do Palangka Raya Muslim Societies Patronize Islamic Banks?
}

\author{
Itsla Yunisva Aviva, ${ }^{1}$ Utari Evy Cahyani, ${ }^{2}$ Rizal Ma'ruf Amidy Siregar3 \\ ${ }^{1}$ Institut Agama Islam Negeri Palangka Raya, ${ }^{2} 3$ Institut Agama Islam Negeri Padangsidimpuan \\ ${ }^{1}$ Jl. G.Obos Komplek Islamic Center, Palangka Raya, Kalimantan Tengah \\ 23 Jl. H.T. Rizal Nurdin Km. 4,5 Sihitang, Padangsidimpuan \\ Email: itslayunisvaaviva@gmail.com, ${ }^{1}$ utari@iain-padangsidimpuan.ac.id, ${ }^{2}$ rizalma@iain- \\ padangsidimpuan.ac.id ${ }^{3}$
}

\begin{abstract}
Abstrak
Tujuan dari makalah ini adalah untuk mengetahui konstruksi teori perilaku yang direncanakan dalam kriteria pemilihan bank syariah pada masyarakat Muslim Palangka Raya. Studi ini berbasis survei yang dilakukan terhadap data primer yang dikumpulkan melalui kuesioner terstruktur. Data dikumpulkan dari 124 nasabah bank syariah di Palangka Raya. Penelitian ini menggunakan regresi berganda dengan variabel sikap, norma subjektif, dan kontrol perilaku yang dipersepsikan sebagai variabel bebas. Hasil penelitian menunjukkan bahwa attitude dan perceived behavioral control berpengaruh positif terhadap niat untuk menggandeng bank syariah di Palangka Raya. Sedangkan norma subjektif tidak berpengaruh. Penelitian ini mengimplikasikan bahwa bank syariah di Palangka Raya harus lebih aktif dalam menampilkan citra diri yang baik dalam praktik perbankan syariah. Membangun citra yang baik berperan penting dalam menentukan sikap nasabah terhadap layanan perbankan syariah. Bank syariah harus memberikan pengalaman terbaik kepada nasabah agar lebih loyal.
\end{abstract}

\section{Kata kunci : Niat, Theory of Planned Behavior, Regresi Berganda}

\begin{abstract}
The purpose of this paper is to investigate the constructs of Planned Behavior Theory in selection criteria for Islamic banks employed by Palangka Raya Muslim societies. This is survey based-study conducted on the primary data collected through structured questionnaire. Data are gathered from 124 customers of Islamic banks in Palangka Raya. This research uses multiple regression with attitude, subjective norm, and perceived behavioral control as independent variables. The results reveal that attitude and perceived behavioral control has a positive influence on intention to patronize Islamic banks in Palangka Raya. While subjective norms have no influence. This study implies that Islamic banks in Palangka Raya should be more active in portraying themselves in good image of the Islamic banking practice. Establishing a good image plays significant role in determining the attitude of the customers about Islamic banking services. Islamic banks must provide the best experience to customers to be more loyal.
\end{abstract}

Keywords: Intention, Theory of Planned Behavior, Multiple Regression

\section{INTRODUCTION}

Islamic banking is the largest sector in the Islamic financial industry with a contribution of $71 \%$ or USD 1.72 trillion of industrial assets (Research and Markets, 2019). Its development over the last three decades has been very rapid and has been 


\section{Why Do Palangka Raya Muslim Societies \\ Patronize Islamic Banks?}

Itsla Yunisva Aviva, dkk

well received by Muslims and non-Muslims as a financial institution (Beik \& Arsyianti, 2008; Iqbal \& Molyneux, 2005). In addition, according to data from the Global Islamic Finance Report 2019, Indonesia ranks first on the Islamic Finance Country Index (IFCI) with a value of 81.93 replacing Malaysia's position which has dominated since 2011. This makes Indonesia the top rank in leadership and potential in Global Islamic Bank and Finance (DDCAP Group, 2019).

In Indonesia, Islamic banking has entered the age of 28 years old. Although it can be said to be late compared to other Muslim countries. Nationally, Islamic banking from May 2020 to June 2020 continued to show positive developments with an increase in Assets (9.22\%), Disbursed Financing / PYD (10.13\%), and Third-Party Funds/ TPF (8.99\%) \%) (Financial Services Authority, 2020). As one of the most important players in the service industry today, Islamic banking is not only present as a financial institution that can fulfill religious obligations among Muslims, but also as an inevitable business need for both customers and potential customers. This requires Islamic banks to understand their perceptions of Islamic banks and the factors that can influence them to continue choosing Islamic banks.

Many previous studies on customer attitudes and perceptions of Islamic banks. Mir et.al (2019) stated that the range of customer service and the length of the relationship between the bank and the customer had a positive impact on customer preferences in choosing Islamic banking. In addition, the reliability of service quality is an important factor for customers to choose Islamic banks. Furthermore, the image of the bank, awareness, sharia compliance and individualism affect attitudes directly and indirectly influence customers' intentions to use Islamic banking in the United Arab Emirates (Kaakeh, Hassan, \& Van Hemmen Almazor, 2019).

Butt et.al (2018) investigated the role of religion and perceptions about Islamic banking among customers in choosing Islamic banking in Pakistan. The results of his research state that customer satisfaction with the services and operations of Islamic banks is the most important dimension in choosing a bank. Further research was carried out by Aaminou et.al (2017) modeling the behavior of Moroccan customers in choosing a bank where new Islamic banks are introduced and operate with conventional banks. The findings show that price, branch proximity and service quality are also important in determining the decision to choose a bank. 
Understanding customer behavior and making them loyal to Islamic banks is very important for the development and sustainability of Islamic banking. This research applying the Theory of Planned Behavior (TPB) as a theoretical framework. This theory integrates four predictors of behavior: attitude, subjective norms, Perceived Behavioral Control (PBC) and behavioral intention. (Ajzen \& Driver, 1992).

Palangka Raya is the capital city of Central Kalimantan province as well as the municipality. The existence of Islamic banks supports the economy of the Muslim societies in Palangka Raya. Palangka Raya has the largest number of branches and subbranches of Islamic banks in Central Kalimantan. Furthermore, assets growth of Islamic banks in the past year reached 10 percent (OJK, 2020). Therefore, it becomes important to see the intention muslim societies in Palangka Raya to patronize Islamic bank. This study identifies the factors that influencing intention to patronize Islamic banking in the context of the Palangka Raya muslim societies.

\section{LITERATURE REVIEW}

Intention is desire to perform a certain behavior. Intention affect to actual behavior. The stronger intention towards behavior, the greater the expectation that the behavior is carried out (Fishbein \& Ajzen, 1975). Furthermore, Ajzen stated that intention is assumed to be able to describe the motivational factors that influence behavior. It does not matter how hard people are willing to try, no matter how they try, to do the behavior (Ajzen, 1991: 181). Intention to use Islamic banks can be interpreted as a desire to obtain saving, financing and services.

Theory of Planned Behavior (TPB) is one approach that widely used in studying the intentions and behavior of individuals in using Islamic banks. This theory assumes that humans are rational and use the information available systematically. Humans also consider the implications of their actions before deciding whether or not to commit certain behaviors.

Theory of Planned Behavior (TPB) is a further development of Theory of Reason Action (TRA) by adding a variable that is not available in TRA, namely perceived behavioral control. Theory of Planned Behavior (TPB) postulates three conceptual that determine intention. First, attitude towards behavior which refers to the extent to which a person has an evaluation or assessment of the behavior. Second, social factors are called subjective norms. Subjective norms refer to a person's perception of social 


\section{Why Do Palangka Raya Muslim Societies}

Patronize Islamic Banks?

Itsla Yunisva Aviva, dkk

pressure to perform or not perform the behavior. Third, perceived behavioral control which refers to the extent to which the ease or difficulty a person feels to perform the behavior (Ajzen, 1991: 188). The main factor in Theory of Planned Behavior (TPB) is an individual's intention to do something behaviorally, just like Theory of Reason Action (TRA).

Theory of Reason Action and Theory of Planned Behavior have been widely used in research related to consumer intentions to use Islamic banking. Ganesan et.al (2020) examines the factors that influence consumer intention of Islamic banks in Malaysia. Dawami (2020) investigating the determinants that influence consumer preferences for Islamic banking products and services. Pitchay et.al (2020) using Theory of Planned Behavior (TPB) as a basic theory to measure the factors that influence the behavior intention of depositors towards Islamic banking services. Ayyub et.al (2020) explored the determinants of consumer and non-user intentions to use Islamic banking in Pakistan. Charag et.al (2019) examining the factors that influence customer intention to adopt Islamic banking. Halid et.al (2019) analyzing customer intentions to use Islamic banking products at Bank Muamalat Manado. Bananuka et.al (2019) investigated the contribution of attitudes, subjective norms to the intention to use Islamic banking services in Uganda.

Aziz et.al (2018) tested aspects of customer behavior for using Islamic banking services in Pakistan. Najakh et.al (2018) analyzing the influence of attitudes, subjective norms and perceived behavioral control on the intention to choose Islamic banks with religiosity as a moderating variable. Kaawaase \& Nalukwago (2017) examined the factors that influence a customer's intention to remain subscribed to an Islamic bank in Uganda. Amin (2017) investigated the influence of several determinants on the decision to choose Islamic mortgage financing. Lajuni et.al (2017) examining the factors that influence customer intention to use Islamic banking products. Sulaiman et.al (2016) investigated the predictive factors for adopting Islamic banking in Uganda. Reni \& Ahmad (2016) examines the determinants of consumer intentions in choosing Islamic banks in Indonesia.

Furthermore, Ali et.al (2015) Furthermore, Ali et.al (2015) examined the determinants of customer intentions regarding personal financing in Islamic banks. Alqasa et.al (2014) investigated the determinants that influence a person's intention to use Islamic banking services in Yemen. Rahman (2014) examining the influence of 
attitudes, subjective norms and perceived behavioral control on intention to conduct transactions in Islamic banks. Echchabi \& Aziz (2012) examined the role of attitudes, subjective norms and perceived behavioral control on the intention to adopt Islamic banking in Morocco. Dzuljastri Abdul \& Abduh (2012) explored the factors that influence their intention to use housing finance of Islamic bank in Malaysia.

\section{Attitude}

Attitude is an individual's positive or negative evaluation of certain behaviors. In addition, attitude is a major predictor that influences an intention to use Islamic banks (Charag et al., 2019; Aziz et al., 2018; Lajuni et al., 2017). This explains that the higher the positive response or positive attitude of a person to use Islamic banks, the stronger intention to transact with Islamic banks. Several previous studies found a significant relationship between attitudes towards intention to use Islamic banks (Ganesan et al., 2020; Dawami, 2020; Pitchay et al., 2020; Ayyub et al., 2019; Bananuka et al., 2019; Kaawaase \& Nalukwago, 2017; Amin, 2017; Sulaiman et al., 2016; Reni \& Ahmad, 2016; Alqasa et al., 2014; Rahman, 2014; Echchabi \& Aziz, 2012; Dzuljastri Abdul \& Abduh, 2012). Furthermore, the results of other studies indicate that attitudes have no effect on customer intentions to use Islamic banks (Halid et al., 2019; Najakh et al., 2018; Ali et al., 2015). The existing review literature provides guidance for further exploration of this phenomenon in the context of Islamic banking. Therefore, the hypotheses to be developed in this study are as follows:

H1: Attitudes have a positive effect on intentions to patronize Islamic banking.

\section{Subjective Norms}

Subjective norms are a perception of social pressure to do or not to do a behavior (Ajzen, 1991). Subjective norms are determined by the presence of normative beliefs and the desire to follow (motivation to comply). (Ajzen, 2005). A person will intend to do or not to do a behavior if he gets encouragement from people who are considered important to him. Previous research has shown that subjective norms have a positive and influential effect on customer intentions to use Islamic banks (Ganesan et al., 2020; Pitchay et al., 2020; Halid et al., 2019; Bananuka et al., 2019; Aziz et al., 2018; Najakh et al., 2018; Kaawaase \& Nalukwago, 2017; Amin, 2017; Lajuni et al., 2017; Reni \& Ahmad, 2016; Alqasa et al., 2014; Rahman, 2014; Echchabi \& Aziz, 2012; Dzuljastri Abdul \& Abduh, 2012). However, different results indicate that subjective norms have no effect 


\section{Why Do Palangka Raya Muslim Societies}

Patronize Islamic Banks?

Itsla Yunisva Aviva, dkk

on consumer intentions to use Islamic banks (Charag et al., 2019; Ayyub et al., 2019; Sulaiman et al., 2016; Ali et al., 2015). The difference results in previous studies suggest the importance of conducting further studies. Therefore, the hypotheses to be developed in this study are as follows:

H2: Subjective norms have a positive influence on intentions to patronize Islamic banking

\section{Perceived behavior control}

Perceived behavioral control is belief about how easy or difficult the behavioral forces are likely to occur (Ajzen \& Madden, 1986: 457). Perceived behavioral control is assumed to be a reflection of past experiences and the anticipation of obstacles. Thus it can be concluded that perceived behavioral control is a function of control beliefs, namely beliefs about the existence of factors that can facilitate or complicate the implementation of a behavior and perceptions about the strength of these factors (Fishbein \& Ajzen, 2005). Previous research has shown that perceived behavioral control has a positive effect on intention to use Islamic banks (Ganesan et al., 2020; Pitchay et al., 2020; Ayyub et al., 2019; Aziz et al., 2018; Rahman, 2014). Meanwhile, the other studies indicate that perceived behavioral control has no effect on the intention to use Islamic bank products (Halid et al., 2019; Najakh et al., 2018). In this study, it is expected that perceived behavioral control have an influence on the intention to use Islamic banking. Therefore, the third hypothesis that can be developed in this study is as follows:

H3: Perceived behavioral control has a positive effect on intention to patronize Islamic banking.

\section{METHODS}

In this research, the data has been collected using structured questionnaire, which was distributed online to the muslim societies in Palangka Raya. The questionnaire contains two main sections. The first one is demographic of the respondents. The second one is designed to collect information about the constructs of the Theory of Planned Behavior. The items under the section are measured using five points likert scale ( $1=$ strongly disagree and $5=$ strongly agree).

Ordinary Least Square (OLS) regression considered more suitable for this research. The dependent variable in this research is intention. While the independent 
variables in this research are attitude, subjective norms, and perceived behavioral control. Based on Gauss-Markov's theory, the estimator obtain Best Linier Unbiased Estimator (BLUE). In this research, the Gauss-Markov assumption test, carried out which consisted of normality test, autocorrelation test, and heteroscedasticity test. Multiple regression was subsequently applied using eviews 9.

The population of this research is muslim citizens in Palangka Raya which amount 186,696. The sample size is determined by Krejcie and Morgan table (Krejcie \& Morgan, 1970). The number of samples based on the table is 377 sample that was randomly selected. A total 377 questionnaires were randomly distributed, 124 respondents have an Islamic bank account.

The researcher formulated Null hypothesis (Ho) and alternative hypothesis (H1) which must be tested. There are criteria of testing by t-test, as follow:

Hypothesis 1

$\mathrm{Ho}_{1}: \beta_{1}=\mathrm{o}$ there is no positive effect attitude on intentions to patronize Islamic banking. $\mathrm{H}_{1}: \beta_{1}>\mathrm{O}$ there is positive effect attitude on intentions to patronize Islamic banking.

Hypothesis 2

$\mathrm{Ho}_{2}: \beta_{2}=\mathrm{O}$ there is no positive effect subjective norms on intentions to patronize Islamic banking.

$\mathrm{H}_{2}: \beta_{2}>\mathrm{O}$ there is positive effect subjective norms on intentions to patronize Islamic banking.

Hypothesis 3

$\mathrm{Ho}_{3}: \beta_{3}=\mathrm{O}$ there is no positive effect perceived behavioral control on intentions to patronize Islamic banking.

$\mathrm{H}_{1}: \beta_{3}>\mathrm{O}$ there is positive effect perceived behavioral control on intentions to patronize Islamic banking.

After normality test, 105 data free from outliers. The regression model used in this research is multiple regression from 105 respondents. The multiple regression equation used in this study are:

\section{Intention $_{i}=\beta_{0}+\beta_{1}$ Attitude $_{i}+\beta_{2}$ Subjective Norms $_{i}$ $+\beta_{3}$ Percieved Behavioral Control $_{i}+\varepsilon_{i}$}

Where $i$ represent respondent in the order of $i, \beta_{0}$ is a constant, $\beta_{1}-\beta_{3}$ are coefficient, Intention (intention to patronize Islamic banking) is independent variable, Attitude, 
Subjective norms and Perceived behavioral control are dependent variable, and $\varepsilon_{i}$ is error term. This study use significance level (a) $5 \%$.

\section{DISCUSSION}

\section{Respondent Characteristics}

Based on research instrument recapitulation, characteristics respondents based on gender are shown in Figure 1. Figure 1. Shows that the majority of respondents are female. Female respondents totaled 57 (55\%). While male respondents totaled 47 (45\%).

Figure 1.

Characteristics of Respondents Based on Gender

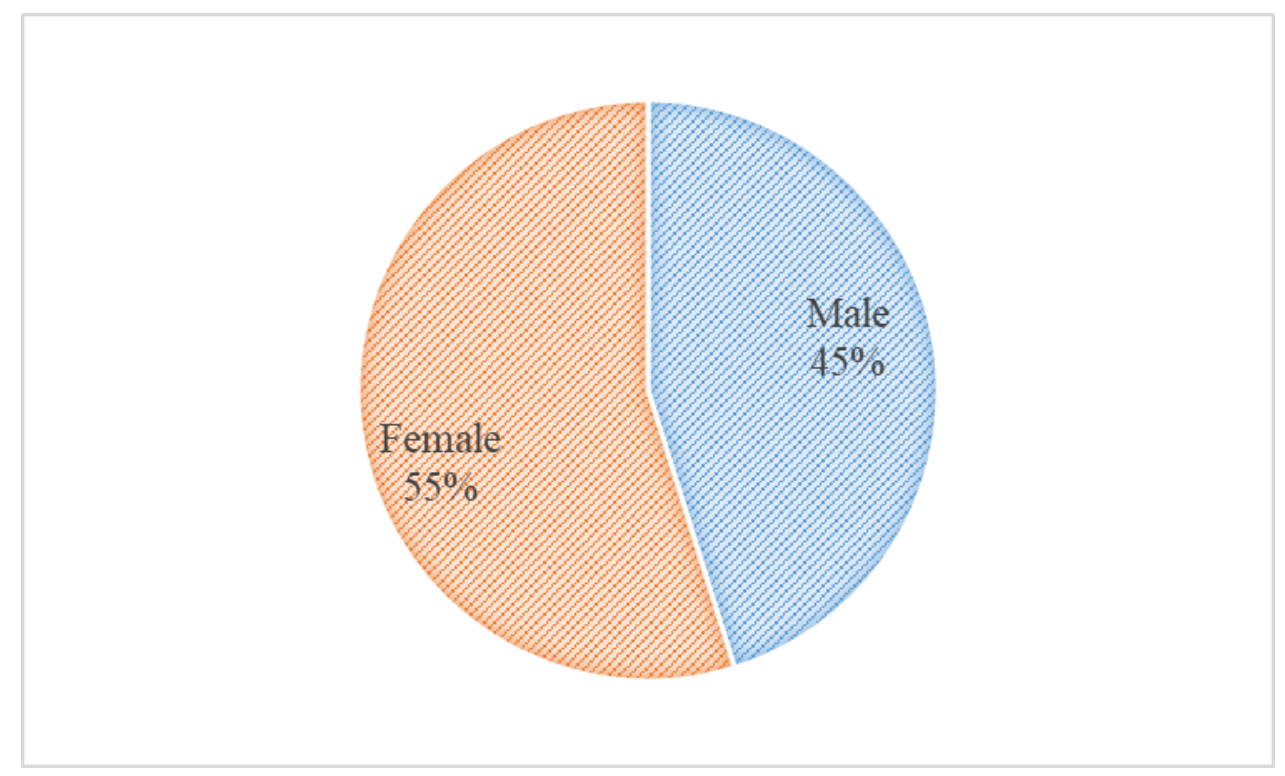

Based on the results of the research instrument recapitulation, characteristics respondents based on educational background are shown in Figure 2. Bachelor is the greatest number as much as $54 \%$ (56 people) of the total respondents. Next followed by respondents with educational background master as much as 29\% (30 people). While respondents with educational background senior high and $\mathrm{PhD}$ each number 13 and 5 respondents. 


\section{Figure 2.}

Characteristics of Respondents Based on Educational Background

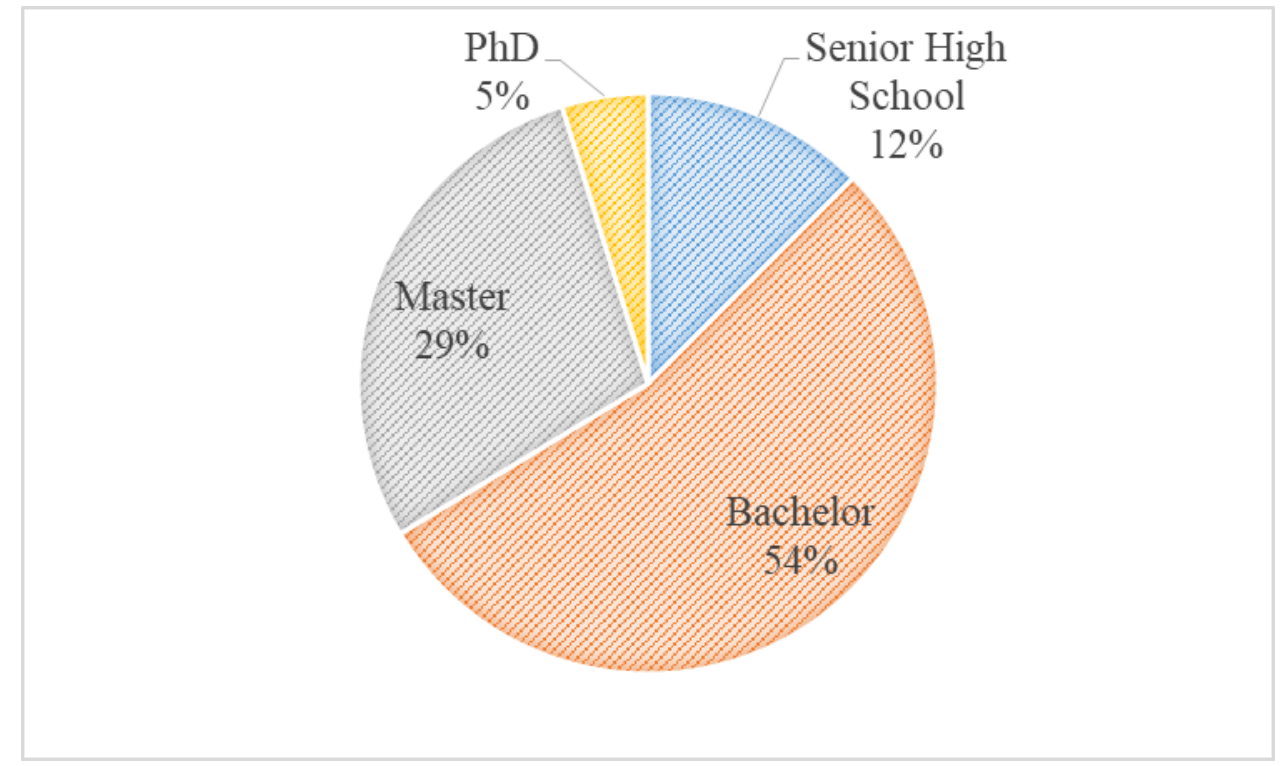

Based on the results of the research instrument recapitulation, characteristics respondents based on occupational background are shown in Figure 3. Most respondents work as private employees as much $43 \%$ (45 people). The number of respondents with occupational background as entrepreneur and government employee is $21 \%$ ( 22 people). The rest is a college student as much $15 \%$ (15 people).

Figure 3.

Respondent Characteristics Based on Occupational Background

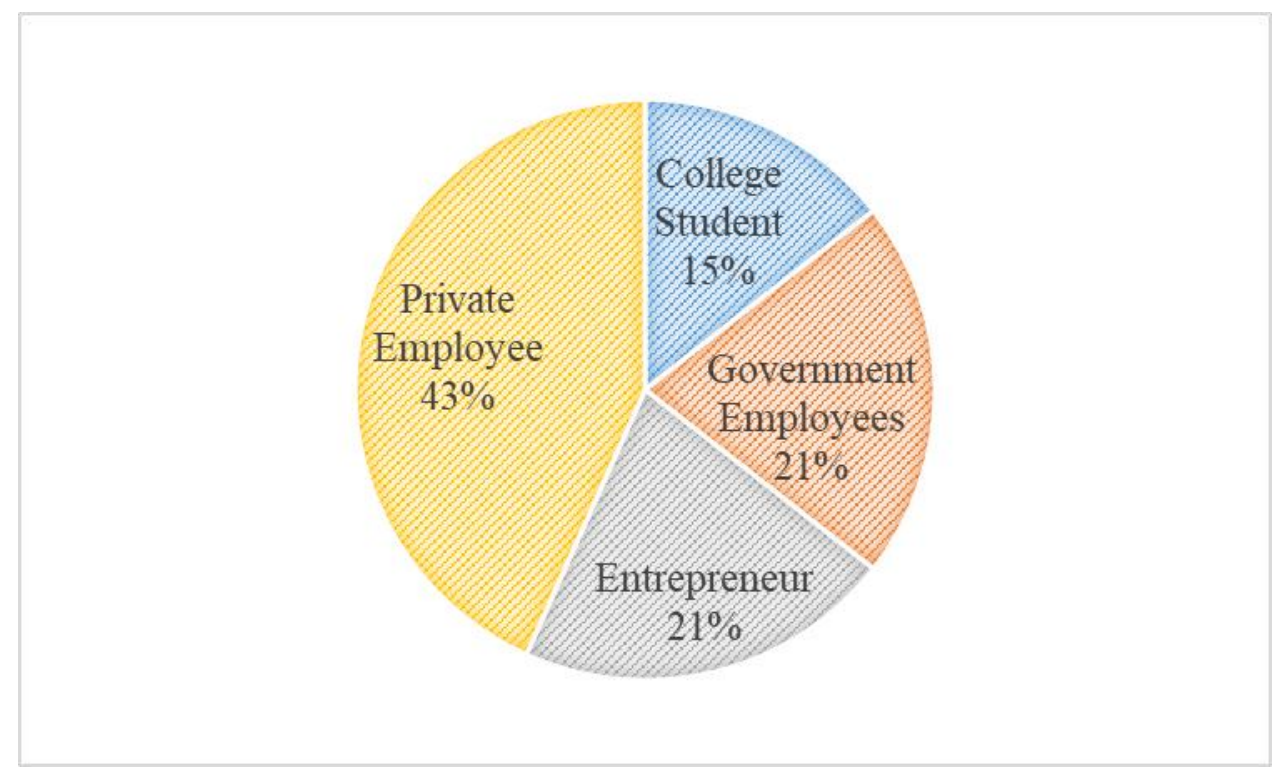


Based on research instrument recapitulation, characteristics respondents based on residential district are shown in Figure 4. There are five district in Palangka Raya city, namely Bukit Batu, Jekan Raya, Pahandut, Rakumpit and Sebangau. Most respondents live in Jekan Raya as much 66 \% (69 people). The number of respondents who live in Pahandut is 25 \% (26 people). Respondents who live in Sebangau, Bukit Batu, and Rakumpit as much as $5 \%$ ( 5 people), $3 \%$ (3 people) and $1 \%$ ( 1 people).

Figure 4

Respondent Characteristics Based on Residential District

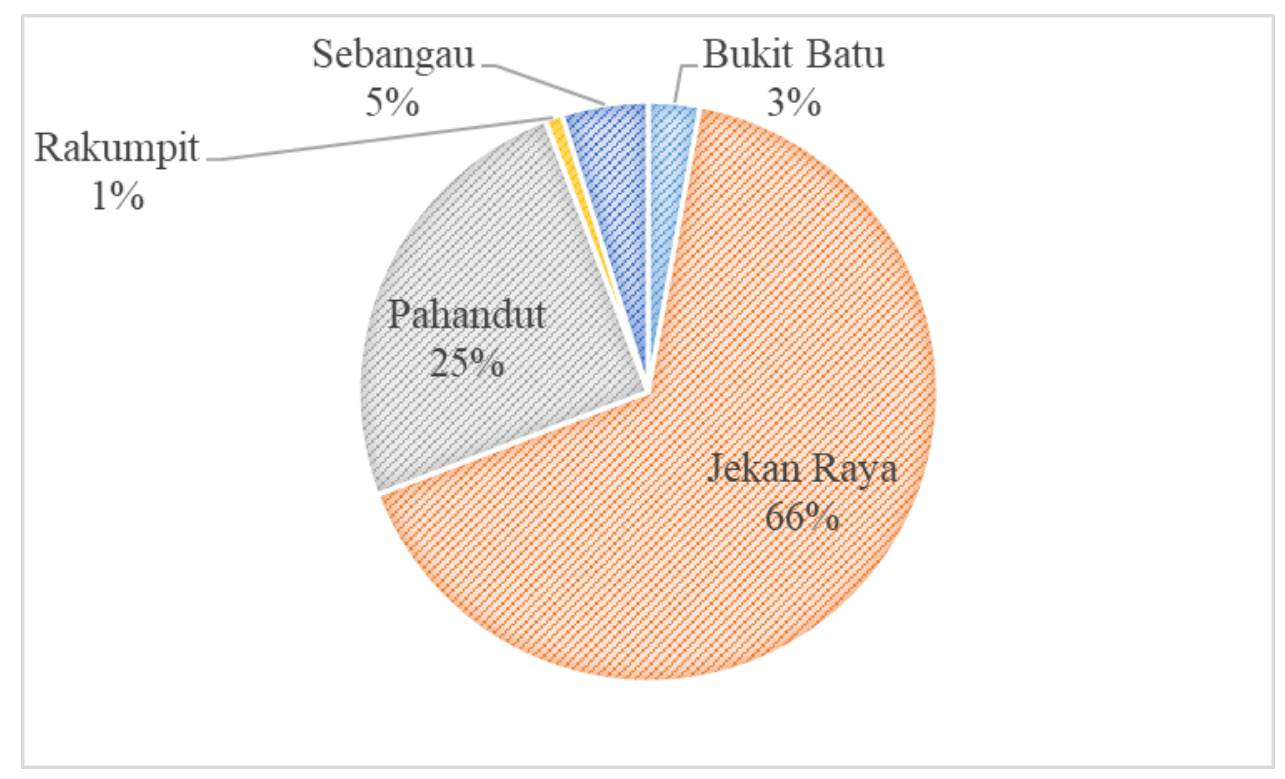

\section{Normality Test}

The hypothesis on the normality test is as follows:

Ho: Residual terdistribusi secara normal

H1: Residual tidak terdistribusi secara normal

Based on the Jarque-Bera statistical test, the statistical value is 5.505127. While the probability value is 0.063764 (greater than 0.05). Therefore, we fail to reject Ho, in other words the residual intention to patronize Islamic banks has a normal distribution.

\section{Autocorrelation Test}

The hypothesis on the autocorrelation test is as follows:

Ho: Tidak ada autokorelasi

H1: Ada autokorelasi 
Based on the Breusch-Godfrey Serial Correlation LM test output, the probability F value is 0.1152 (greater than 0.05). Therefore, we fail to reject Ho in other words there is no autocorrelation.

\section{Heteroscedasticity Test}

The hypothesis on the heteroscedasticity test is as follows:

Ho: Homoskedastisitas

H1: Heteroskedastisitas

Based on the White Test, the probability F value is 0.0004 (less than 0.05). Then reject Ho, which means there are heteroscedasticity. This condition must be improved by estimating the original data with Generalize Least Square (GLS). However, after estimating by weighting the independent variables with variance, standard deviation, inverse variance, and inverse standard deviation, the problem of heteroscedasticity remains. Therefore, this study uses the white method, which is heteroscedasticitycorrected standard errors.

\section{Regression Results}

The results of multiple regression to identify the effect of Attitudes, Subjective Norms and Perceived Behavior Control shown in table 1. The coefficient of determination (adjusted R-square) equation is 0.595354 , or $59.53 \%$. This value indicate that the variation of intention to patronize Islamic bank can be explained by the variation of attitude, subjective norms, and perceived behavioral control of $59.53 \%$. The rest is explained by other variables outside the model.

Table 1

Regression Results

\begin{tabular}{lcccc}
\multicolumn{1}{c}{ Variable } & Coefficient & Std. Error & t-Statistic & Prob. \\
\hline C & -0.820706 & 2.207651 & -0.371755 & 0.7109 \\
Attitude & 0.464587 & 0.144832 & 3.207770 & 0.0018 \\
Subjective Norms & 0.066363 & 0.071243 & 0.931510 & 0.3538 \\
Percieved Behavioral Control & 0.823778 & 0.217515 & 3.787220 & 0.0003 \\
R-Square & 0.607140 & & & \\
Adjusted R-Square & 0.595354 & & &
\end{tabular}


Based on the regression results, the probability value of attitude is $0.0018<0.05$, while the coefficient value is positive. This means that there is a positive influence attitude on intention to patronize Islamic bank in Palangka Raya. The coefficient value 0.464587 indicate that, every 1 unit increase in attitude, the intention will increase by 0.464587 unit. The probability value of subjective norms is $0.3538>0.05$. This means that there is no influence subjective norms on intention to patronize Islamic bank in Palangka Raya. The probability value of perceived behavioral control is $0.0003<0.05$, while the coefficient value is positive. This means that there is positive influence perceived behavioral control on intention to patronize Islamic bank in Palangka Raya. The coefficient value 0.823778 indicate that, every 1 unit increase in perceived behavioral control, the intention will increase by 0.823778 unit.

There are two variable independents that have positive influence on intention to patronize Islamic bank in Palangka Raya, namely attitude and perceived behavioral control. While one variable independent have no effect, namely subjective norms. The research hypothesis can be seen in Table 2.

Table 2

Summary of Hypothesis Testing

\begin{tabular}{|l|l|l|c|c|c|}
\hline & \multicolumn{1}{|c|}{ Variable } & \multicolumn{1}{|c|}{ Hypothesis } & \multicolumn{2}{c|}{ Result } \\
\cline { 3 - 6 } & & & Probability & Coefficient & Decision \\
\hline H1 & Attitude & $\begin{array}{l}\text { Attitudes have a positive } \\
\text { effect on intentions to } \\
\text { patronize Islamic } \\
\text { banking. }\end{array}$ & 0.0018 & 0.464587 & Accepted \\
\hline H2 & $\begin{array}{l}\text { Subjective } \\
\text { Norms }\end{array}$ & $\begin{array}{l}\text { Subjective norms have a } \\
\text { positive effect on } \\
\text { intentions to patronize } \\
\text { Islamic banking. }\end{array}$ & 0.3538 & 0.066363 & Rejected \\
\hline H3 & $\begin{array}{l}\text { Percieved } \\
\text { Behavioral } \\
\text { Control }\end{array}$ & $\begin{array}{l}\text { Percieved behavioral } \\
\text { control have a positive } \\
\text { effect on intentions to } \\
\text { patronize Islamic } \\
\text { banking. }\end{array}$ & 0.0003 & 0.823778 & Accepted \\
\hline
\end{tabular}


Based on the probability and coefficient value, hypothesis 1 which reads attitudes have a positive effect on intentions to patronize Islamic banking is accepted. The results of this study support of previous studies which stated that attitude have a positive effect on intention to patronize Islamic banks (Allah Pitchay et al., 2020; Alqasa et al., 2014; Amin, 2017; Ayyub et al., 2019; Bananuka et al., 2019; Dawami, 2020; Dzuljastri Abdul \& Abduh, 2012; Echchabi \& Aziz, 2012; Ganesan et al., 2020; Kaawaase \& Nalukwago, 2017; Rahman, 2014; Reni \& Ahmad, 2016; Sulaiman et al., 2016). It is imply that Islamic banks in Palangka Raya should be more active in portraying themselves in good image of the Islamic banking practice. Establishing a good image plays significant role in determining the attitude of the customers about Islamic banking services.

Based on the probability and coefficient value, hypothesis 2 which reads subjective norms have a positive effect on intentions to patronize Islamic banking is rejected. The results of this study not in line with previous studies which stated that subjective norms have a positive effect on intention to patronize Islamic banks (Allah Pitchay et al., 2020; Alqasa et al., 2014; Amin, 2017; Aziz et al., 2018; Bananuka et al., 2019; Dzuljastri Abdul \& Abduh, 2012; Echchabi \& Aziz, 2012; Ganesan et al., 2020; Halid et al., 2019; Lajuni et al., 2017; Najakh et al., 2018; Rahman, 2014; Reni \& Ahmad, 2016). However, this research in line with previous studies which stated that subjective norms have no effect on intention (Ali et al., 2015; Ayyub et al., 2019; Charag et al., 2019; Sulaiman et al., 2016).

Hypothesis 3 which reads perceived behavioral control have a positive effect on intentions to patronize Islamic banking is accepted based on probability and coefficient output. This results in line with previous studies which stated that perceived behavioral control have a positive effect on intention (Allah Pitchay et al., 2020; Ayyub et al., 2019; Aziz et al., 2018; Ganesan et al., 2020; Rahman, 2014). It is imply that Islamic banks in Palangka Raya must provide the best experience to customers to be more loyal.

\section{CONCLUSION}

This study was conducted to investigate the constructs of Planned Behavior Theory in selection criteria for Islamic banks employed by Palangka Raya Muslim societies. This is survey based-study conducted on the primary data collected through structured questionnaire. Data are gathered from 124 customers of Islamic banks in Palangka Raya. This research uses multiple regression with attitude, subjective norm, 


\section{Why Do Palangka Raya Muslim Societies}

Patronize Islamic Banks?

Itsla Yunisva Aviva, dkk

and perceived behavioral control as an independent variables. The results reveal that attitude and perceived behavioral control has a positive influence on intention to patronize Islamic banks in Palangka Raya. While subjective norm have no influence on intention to patronize Islamic banks in Palangka Raya.

Based on research results, it is imply that Islamic banks in Palangka Raya should be more active in portraying themselves in good image of the Islamic banking practice. Establishing a good image plays significant role in determining the attitude of the customers about Islamic banking services. Moreover, Islamic banks must provide the best experience to customers so that customers are satisfied and ultimately become loyal.

\section{REFERENCES}

Aaminou, M. W., Finance, I., Aboulaich, R., \& Finance, I. (2017). Modeling Consumers ' Behavior in New Dual Banking Markets: The Case of Morocco, 2O(2), 1-24. https://doi.org/10.1142/So219091517500096

Ajzen, I. (1991). The Theory of Planned Behavior. Organizational Behavior and Human Decision Processes, 50(2), 179-211.

Ajzen, I. (2005). Attides, Personallity and Behavior. International Journal of Strategic Innovative Marketing.

Ajzen, I., \& Driver, B. L. (1992). Application of the Theory of Planned Behavior to Leisure Choice. Journal of Leisure Research, 24(3), 207-224. https://doi.org/10.1080/00222216.1992.11969889

Ajzen, I., \& Madden, T. J. (1986). Prediction of goal-directed behavior: Attitudes, intentions, and perceived behavioral control. Journal of Experimental Social Psychology, 22(5), 453-474. https://doi.org/10.1016/0022-1031(86)90045-4

Ali, M., Raza, S. A., \& Puah, C.-H. (2015). Factors affecting intention to use Islamic personal financing in Pakistan : Evidence from the modified TRA model . Munich Personal RePEc Archive, (66023), 1-27.

Allah Pitchay, A. Bin, Mohd Thas Thaker, M. A. Bin, Azhar, Z., Mydin, A. A., \& Mohd Thas Thaker, H. Bin. (2020). Factors persuade individuals' behavioral intention to opt for Islamic bank services: Malaysian depositors' perspective. Journal of Islamic Marketing, 11(1), 234-250. https://doi.org/10.1108/JIMA-02-2018-0029

Alqasa, K. M., Isa, F. M., Othman, S. N., \& Zolait, A. H. S. (2014). The impact of 
students' attitude and subjective norm on the behavioural intention to use services of banking system. International Journal of Business Information Systems, 15(1), 105-122. https://doi.org/10.1504/IJBIS.2014.057967

Amin, H. (2017). Explaining The Decision to Choose Islamic Mortgage Financing : The Case of East Malaysia. International Journal of Business and Society, 18(1), 177192.

Ayyub, S., Xuhui, W., Asif, M., \& Ayyub, R. M. (2019). Determinants of intention to use Islamic banking: A comparative analysis of users and non-users of Islamic banking: evidence from Pakistan. International Journal of Islamic and Middle Eastern Finance and Management, 13(1), 147-163. https://doi.org/10.1108/IMEFM-052017-0135

Aziz, S., Afaq, Z., \& Bashir, U. (2018). Behavioral Intention to Adopt Islamic Banking in Pakistan: A Study Based on Theory of Planned Behavior. Journal of Islamic Business and Management (JIBM), 8(2), 407-422. https://doi.org/10.26501/jibm/2018.0802-005

Bananuka, J., Kaawaase, T. K., Kasera, M., \& Nalukenge, I. (2019). Determinants of the intention to adopt Islamic banking in a non-Islamic developing country: The case of Uganda. ISRA International Journal of Islamic Finance, 11(2), 166-186. https://doi.org/10.1108/IJIF-04-2018-0040

Beik, I. S., \& Arsyianti, L. D. (2008). Why The Rate Of Financing In Islamic Banks Is High? An Analysis Based On Malaysian Case. TAZKIA : Islamic Finance \& Business Review, 3(1), 18-29.

Butt, I., Ahmad, N., \& Ahmed, Z. (2018). Determinants of low adoption of Islamic banking in Pakistan, 9(3), 655-672. https://doi.org/10.1108/JIMA-01-2017-0002

Charag, A. H., Fazili, A. I., \& Bashir, I. (2019). Determinants of consumer's readiness to adopt Islamic banking in Kashmir. JIMA : Journal of Islam Marketing, Emerald Pu(1759-0833), 1-30. https://doi.org/10.1108/JIMA-10-2018-0182

Dawami, Q. (2020). Factors Influencing The Preference Of Customers Towards Islamic Banking : Evidence From Malaysia. Journal of Islamic Economic Laws, 3(1), 4867.

DDCAP Group. (2019). Islamic Finance Country Index 2019. In Global Islamic Finance Report 2019 (pp. 49-78).

Dzuljastri Abdul, R., \& Abduh, M. (2012). Customers Attitude towards Diminishing 


\section{Why Do Palangka Raya Muslim Societies}

Patronize Islamic Banks?

Itsla Yunisva Aviva, dkk

Partnership Home Financing in Islamic Banking. American Journal of Applied Sciences, 9(4), 593-599.

Echchabi, A., \& Aziz, H. A. (2012). Empirical Investigation of Customers 'Perception and Adoption Towards Islamic Banking Services in Morocco. Middle-East Journal of Scientific Research, 12(6), 849-858. https://doi.org/10.5829/idosi.mejsr.2012.12.6.1942

Fishbein, M., \& Ajzen, I. (1975). Belief, Attitude, Intention, and Behavior: An Introduction to Theory and Research.

Fishbein, M., \& Ajzen, I. (2005). The Influence of Attitudes on Behavior. In D. Albarracín, B. T. Johnson, \& M. P. Zanna (Eds.), The Handbook of Attitudes (pp. 173-220). New York: Psychology Press. https://doi.org/10.1007/BFo2294218

Ganesan, Y., Allah Pitchay, A. Bin, \& Mohd Nasser, M. A. (2020). Does intention influence the financial literacy of depositors of Islamic banking? A case of Malaysia. International Journal of Social Economics, 47(5), 675-690. https://doi.org/10.1108/IJSE-01-2019-0011

Halid, S. N., Worang, F. G., \& Tumewu, F. (2019). Application of Theory Planned Behavior and Influence on Customer's Intention Adopting Islamic Banking Product, $7(4), 5029-5038$.

Iqbal, M., \& Molyneux, P. (2005). Thirty Years of Islamic Banking. Thirty Years of Islamic Banking. New York: Houndmills. https://doi.org/10.1057/9780230503229

Kaakeh, A., Hassan, M. K., \& Van Hemmen Almazor, S. F. (2019). Factors affecting customers' attitude towards Islamic banking in UAE. International Journal of Emerging Markets, 14(4), 668-688. https://doi.org/10.1108/IJOEM-11-20170502

Kaawaase, T. K., \& Nalukwago, L. (2017). Religiosity and Islamic Banking in Uganda. Makerere Business Journal, 13(1), 70-93. https://doi.org/10.33117/513

Krejcie, R. V., \& Morgan, D. W. (1970). Determining Sample Size for Research Activities. Educational and Psychological Measurement, 30, 607-610. https://doi.org/10.1261/rna.2763111

Lajuni, N., Wong, W., Ming, P., Yacob, Y., Ting, H., \& Jausin, A. (2017). International Journal of Economics and Financial Issues Intention to Use Islamic Banking Products and Its Determinants. International Journal of Economics and Financial Issues, 7(1), 329-333. 
Mir, M. M., Iftikhar, D., \& Ahsan, O. (2019). Factors Influence the Adoption of the Islamic Banking System : Customers Perception in Pakistan, 18(2), 275-286.

Najakh, A. K., Astogini, D., \& Martini, S. (2018). The Influence of Attitudes, Subjective, Norms, and Behavior Controls on Intention to Choose Islamic Banks With Islamic Religiosity as a Moderating Variable (Case Study at Bri Syariah Purwokerto Customers). Journal of Economicate Studies, 2(1). https://doi.org/10.32506/joes.v2i1.464

OJK. (2020). Sharia Banking Statistics.

Otoritas Jasa Keuangan. (2020). Snapshot Perbankan Syariah Per Juni 2020. Snapshot Perbankan Syariah.

Rahman, T. (2014). Analisis determinan minat individu dosen dan mahasiswa terhadap bank syariah. Muqtasid, 5(1), 53-74.

Reni, A., \& Ahmad, N. H. (2016). Application of Theory Reasoned Action in Intention To Use Islamic Banking in Indonesia. Al-Iqtishad: Journal of Islamic Economics, 8(1), 137-148. https://doi.org/10.15408/aiq.v8i1.2513

Research and Markets. (2019, March). Global Islamic Finance Markets Report 2019: Islamic Banking is the Largest Sector, Contributing to $71 \%$, or USD 1.72 Trillion. Globe Newswire.

Sulaiman, L., Moammad, M. O., \& Hassan, R. (2016). Modelling public behavioral intention to adopt Islamic banking in Uganda: the theory of reasoned action. International Journal of Islamic and Middle Eastern Finance and Management, 9(4), 583-600. 